\title{
EFEK GEL EKSTRAK HERBA PEGAGAN (Centella asiatica L. Urban) DENGAN GELLING AGENT HIDROKSIPROPIL METHYLCELLULOSE TERHADAP PENYEMBUHAN LUKA BAKAR PADA KULIT PUNGGUNG KELINCI
}

\author{
Tanti Azizah Sujono1, Ullya Nur Wahyu Hidayah², T.N. Saifullah Sulaiman² \\ ${ }^{1}$ Fakultas Farmasi Universitas Muhammadiyah Surakarta \\ ${ }^{2}$ Fakultas Farmasi Universitas Gadjah Mada \\ Email : tanti_azizah@ums.ac.id
}

\begin{abstract}
Pegagan (Centella asiatica L. Urban) contain saponin asiaticoside, which is a structural protein. The compound plays a role in the wound healing process by the formation of collagen. This research was conducted to determine the effect of wound healing of burns on New Zealand male rabbits using gel extract of Pegagan (Centella asiatica L. Urban) herbs using hydroxypropyl methylcellulose (HPMC) as gelling agent. This research was an experimental with the same subject design, using five male New Zealand rabbits to test the wound healing of burns, and the backs of each rabbit were divided into six treatment i.e : positive control (Bioplasenton), negative control (no treatment), control HPMC base (no extract), and three formula with herbal extracts of Centella asiatica with a concentration of gelling agent HPMC $8 \%, 9 \%$, and $10 \%$ respectively. Gel was applied to the back of rabbits with the use \pm 0.3 grams once daily until the wound diameter equal to zero or until healed. The data was analyzed by one way anava with a 95\% confidence level. The result showed that of the gelling agent HPMC concentration effect on the increased the viscosity, and decreased the spreadability and the burn wound healing time is a longer. Gel herb pegagan extract (Centella asiatica L. Urban) with a gelling agent HPMC concentration of $8 \%(17,60 \pm 1,14$ days) most effectively heal burns compared to the concentration of $9 \%(19,40 \pm 1,14$ days) and concentration $10 \%(20,40 \pm 1,14$ days $)$.
\end{abstract}

Keywords: Centella asiatica L. Urban, gel, hydroxypropyl methylcellulose, burns.

\section{PENDAHULUAN}

Luka bakar merupakan respon kulit dan jaringan subkutan terhadap trauma termal atau suhu (Grace \& Borley, 2007). Penyebab luka bakar bermacam-macam diantaranya api, uap panas, cairan panas, bahkan bahan kimia, aliran listrik. Pengobatan menggunakan tanaman obat sebagai penyembuh luka bakar akhir-akhir ini banyak digunakan, salah satunya adalah menggunakan herba pegagan (Centella asiatica L. Urban) (Wasito, 2011). Penggunaan tradisional herba pegagan sebagai obat luka bakar yaitu dengan mencuci bersih herba pegagan segar, digiling dan langsung ditempelkan pada bagian yang luka (Sudarsono et al., 2002).

Pegagan mengandung asiaticoside (Sikarrepaisan et al., 2008), suatu saponin yang memacu pembentukan kolagen, yaitu protein struktur yang berperan dalam proses penyembuhan luka (MacKay \& Miller, 2003), selain itu juga mengandung senyawa fenolik, flavonoid, minyak atsiri. Beberapa penelitian telah dilakukan untuk mengetahui aktivitas pegagan sebagai antimikroba, antifungi, dan antioksidan (Lee \& Vairappan, 2011), serta antikanker (Kim et al., 2009). Penggunaan herba pegagan sebagai obat penyembuh luka bakar dapat dipermudah dengan memformulasikannya dalam sediaan gel. Kandungan air yang tinggi dalam basis gel dapat menyebabkan terjadinya hidrasi pada stratum corneum sehingga akan memudahkan penetrasi obat melalui kulit (Kibbe, 2004).

Penelitian Rismana (2010) menunjukkan bahwa gel ekstrak herba pegagan $0,5 \%$ dengan 
gelling agent kitosan 1,5\% mampu menyembuhkan luka bakar setelah 22 hari. Penelitian Suratman et al., (1996) menggunakan ekstrak herba pegagan 3\% dan 5\% dengan gelling agent karbopol 940 sebesar 2\% mampu menyembuhkan luka bakar setelah 11 hari.

Salah satu basis gel derivat selulosa adalah hidroksipropil metilselulose (HPMC) (Gibson, 2001). Hidroksipropil metilselulose adalah turunan selulosa eter semisintetik yang telah digunakan secara luas sebagai polimer hidrofilik dalam sistem pemberian obat oral dan topikal (Rogers, 2009). Pemilihan basis HPMC dikarenakan penampakan gel jernih dan kompatibel dengan bahan-bahan lain, kecuali bahan-bahan yang oksidatif (Gibson, 2001) serta dapat mengembang terbatas dalam air sehingga merupakan bahan pembentuk hidrogel yang baik (Suardi et al., 2008). Selain itu substitusi pada metil memberi satu ciri unik HPMC yaitu kekuatan gel dan gel terbentuk pada suhu $60-90^{\circ} \mathrm{C}$ tergantung substitusi polimer dan konsentrasi pada air (Roger, 2009). Hasil penelitian Madan \& Singh (2010) menyebutkan basis HPMC memiliki kemampuan daya sebar yang lebih baik dari karbopol, metilselulosa, dan natrium alginat, sehingga mudah diaplikasikan ke kulit. Gel yang baik mempunyai waktu penyebaran yang singkat.

Berdasarkan latar belakang di atas, maka perlu dilakukan penelitian tentang efek penyembuhan luka bakar pada punggung kelinci jantan menggunakan gel ekstrak herba pegagan dengan variasi konsentrasi gelling agent yang berbeda yaitu HPMC

\section{METODOLOGI PENELITIAN}

\section{Alat dan Bahan}

Alat : pembuat luka (penginduksi panas/ lempeng logam dengan diameter 2 $\mathrm{cm}$ yang dihubungkan pada sebuah solder), termometer, stopwatch, jangka sorong, alat-alat gelas (Pyrex), Viscotester RION (VT04E RION), rotary evaporator (Reidolph).

Bahan : Simplisia herba pegagan (CV. Merapi Farma Herbal), HPMC SH 60 (Bratachem), metilparaben (Bate Chemical Co.Ltd.), propilparaben (Bate Chemical Co.Ltd.), propilenglikol bioplasenton, etanol $96 \%$.

Hewan uji : kelinci jantan New Zealand White sehat dengan umur 2,5-3 bulan

\section{Jalannya Penelitian}

\section{Pembuatan Ekstrak Herba Pegagan}

Simplisia herba pegagan $500 \mathrm{mg}$ dimaserasi menggunakan 10 liter etanol 96\% selama 3 hari sambil sesekali diaduk, selanjutnya filtrat diuapkan di atas waterbath sampai diperoleh ekstrak kental.

\section{Pembuatan Gel Ekstrak Herba Pegagan dengan Gelling Agent HPMC}

Tabel 1. Formula pembuatan gel ekstrak herba Pegagan

\begin{tabular}{ccccc}
\hline Komposisi & F 1 & F2 & F3 & F4 \\
\hline Ekstrak $(\mathrm{g}) *$ & - & 3 & 3 & 3 \\
HPMC $(\mathrm{g}) * *$ & 8 & 8 & 9 & 10 \\
Metilparaben $(\mathrm{g})$ & 0,18 & 0,18 & 0,18 & 0,18 \\
Propilenglikol $(\mathrm{g})$ & 15 & 15 & 15 & 15 \\
Propilparaben $(\mathrm{g})$ & 0,15 & 0,15 & 0,15 & 0,15 \\
Aquadest ad $(\mathrm{mL})$ & 100 & 100 & 100 & 100 \\
\hline
\end{tabular}

* Konsentrasi ekstrak pegagan yang digunakan didapatkan dari penelitian Suratman et al., (1996)

** Variasi konsentrasi HPMC yang digunakan didapatkan setelah melakukan uji pendahuluan

Gel diformulasikan sesuai komposisi pada tabel 1, ditimbang masing-masing bahan. HPMC didispersikan ke dalam $30 \mathrm{ml}$ air pada suhu $\left(80-90^{\circ} \mathrm{C}\right)$ hingga mengembang dan diaduk sampai terbentuk liat (gel). Pengadukan harus dalam keadaan dingin yaitu di dalam baskom yang telah diberi es batu. Metilparaben dan propilparaben dicampur dalam propilenglikol $15 \mathrm{ml}$ lalu ekstrak dimasukkan hingga tercampur. Campuran tersebut dimasukkan dalam campuran HPMC liat dan diaduk sampai homogen. Ditambah air dingin hingga didapat 100,0 gram gel, kemudian dikemas dalam tube yang tertutup rapat.

\section{Uji Sifat Fisik Gel}

Uji sifat fisik gel antara lain pemeriksaan organoleptis, $\mathrm{pH}$, viskositas, waktu lekat, daya sebar, dan homogenitas.

\section{Uji Stabilitas Gel}

Gel ekstrak herba pegagan diuji stabilitasnya pada suhu kamar dengan mengamati warna, bau, konsistensi, $\mathrm{pH}$, dan viskositas setiap hari ke-0, ke-7, ke-14, ke-21, ke-28, ke-35, ke-42. 


\section{Pembuatan Luka Bakar}

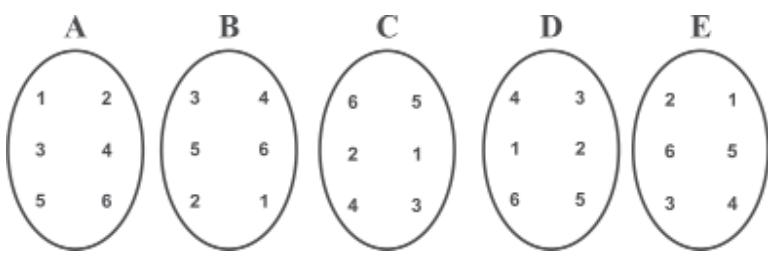

Gambar 1. Model lokasi pembuatan luka bakar di bagian kulit punggung kelinci

\section{Keterangan}

$\begin{array}{cccc}1 & \text { Tidak diberi perlakuan } & \text { A } & \text { Kelinci ke-1 } \\ 2 & \text { Kontrol positif }\left(\text { Bioplacenton }{ }^{\circledR}\right) & \text { B } & \text { Kelinci ke-2 } \\ 3 & \text { F1 (HPMC 8\%) } & \text { C } & \text { Kelinci ke-3 } \\ 4 & \text { F2 (HPMC 8\%+ekstrak) } & \text { D } & \text { Kelinci ke-4 } \\ 5 & \text { F3 (HPMC 9\%+ekstrak) } & \text { E } & \text { Kelinci ke-5 } \\ 6 & \text { F4 (HPMC 10\%+ekstrak) } & & \end{array}$

Pembuatan luka bakar dilakukan dengan alat penginduksi panas suhu $80^{\circ} \mathrm{C}$, selama 5 detik. Sebelum diinduksi bulu pada bagian punggung dicukur terlebih dahulu dan dianestesi menggunakan etil klorida dengan cara disemprotkan pada kulit yang akan dibuat luka bakar. Alat penginduksi panas berupa lempeng logam dengan diameter $2 \mathrm{~cm}$ yang dihubungkan dengan sebuah elemen panas yang mempunyai daya 40 Watt dan tegangan 220 Volt. Jarak masingmasing luka bakar $5 \mathrm{~cm}$ (Suratman et al., 1996).

\section{Pengujian Lama Penyembuhan Luka Bakar Gel Herba Pegagan}

Digunakan 5 hewan uji kelinci jantan yang punggungnya telah dibuat luka bakar, kemudian diolesi $\pm 0,3$ gram gel sekali sehari, lalu ditutup dengan kain kasa steril dan plester.

\section{Analisis Data}

Data yang diperoleh dari penelitian berupa diameter luka bakar $(\mathrm{cm})$ yang diukur dengan jangka sorong (Einbill) (Gambar 2). Diameter luka bakar yang diperoleh dihitung dengan menggunakan rumus:

$$
d x=\frac{d x 1+d x 2+d x 3+d x 4}{4}
$$

$\mathrm{dx}$ : diameter pada hari ke $\mathrm{x}$

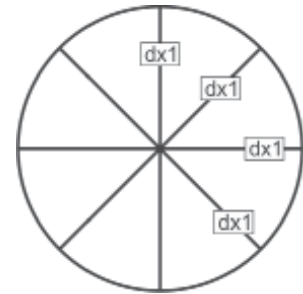

Gambar 2. Cara mengukur diameter luka bakar (Suratman et al, 1996).

Lalu dihitung persentase penyembuhan luka bakar dengan rumus sebagai berikut: (Suratman $e t$ al, 1996)

$$
p x=\frac{d 1^{2}+d x^{2}}{d 1^{2}} \times 100 \%
$$

$\mathrm{Px}=$ persentase penyembuhan luka bakar pada hari ke-x

$\mathrm{d}_{1}=$ diatemer luka bakar hari pertama

$\mathrm{dx}=$ diameter luka bakar hari ke- $\mathrm{x}$

Data lama penyembuhan luka bakar (hari) diuji statistik dengan uji Kolmogorov-Smirnov untuk mengetahui normalitas distribusi data, dan Levene test untuk mengetahui homogenitas varian. Karena data terdistribusi normal dan homogen maka dilakukan uji statistik analisis varian satu jalan, dilanjutkan dengan uji LSD (Least Significant different) dengan taraf kepercayaan 95\%.

\section{HASIL DAN PEMBAHASAN}

\section{A. Uji Pendahuluan Konsentrasi Basis HPMC SH 60}

Uji pendahuluan dilakukan untuk mencari konsentrasi HPMC SH 60 yang dapat diformulasikan dalam sediaan gel ekstrak herba pegagan dengan konsistensi yang tidak encer.

Tabel 2. Hasil uji pendahuluan konsentrasi Basis HPMC SH 60

\begin{tabular}{ccc}
\hline $\begin{array}{c}\text { Konsentrasi } \\
\text { HPMC SH } 60(\%)\end{array}$ & $\begin{array}{c}\text { Sebelum } \\
\text { ditambah ekstrak }\end{array}$ & $\begin{array}{c}\text { Setelah } \\
\text { ditambah ekstrak }\end{array}$ \\
\hline 1 & Encer & Encer \\
2 & Encer & Encer \\
3 & Encer & Encer \\
4 & Encer & Encer \\
5 & Encer & Encer \\
6 & Encer & Encer \\
7 & Agak kental & Encer \\
8 & Kental & Kental \\
9 & Kental & Kental \\
10 & Kental & Kental \\
\hline
\end{tabular}


Hasil konsentrasi HPMC SH 60 1\% hingga $7 \%$ sebelum dan setelah penambahan ekstrak didapatkan gel yang masih encer, sehingga tidak digunakan dalam penelitian (Tabel 2), hal ini dikarenakan jika konsistensi gel yang encer akan sulit diaplikasikan dalam punggung kelinci, karena akan mudah mengalir sehingga pengobatannya kurang optimal. Konsentrasi 8\%, 9\%, dan 10\% menghasilkan gel dengan konsistensi yang kental sebelum dan setelah penambahan ekstrak. Pada HPMC SH 60 memiliki rentang konsentrasi 7-12\% agar dapat terbentuk gel (Rogers, 2009), dalam penelitian ini konsentrasi yang digunakan adalah $8 \%, 9 \%$, dan $10 \%$, sehingga sudah sesuai dengan standar rentang konsentrasi basis HPMC SH 60.

\section{A. Sifat Fisik Gel}

\section{Hasil Uji Organoleptis, pH, dan Homogenitas}

Pembuatan ekstrak herba pegagan dilakukan dengan cara maserasi. Pelarut yang digunakan dalam ekstraksi yaitu etanol 96\%, yang dapat menarik senyawa kimia asiaticoside yang terkandung dalam pegagan. Pemilihan etanol 96\% (bersifat polar) karena zat aktif yang hendak disari yaitu asiaticoside yang merupakan saponin yang bersifat polar sehingga lebih mudah ditarik oleh penyari yang bersifat polar (like dissolve like). Hasil maserasi dan remaserasi 500 gram herba pegagan diperoleh ekstrak kental berwarna coklat kehijauan sebesar 50,62 gram dan rendemen yang diperoleh $10,12 \%$, sehingga sudah sesuai dengan standar bahwa hasil rendemen tidak kurang dari 7,2\%. (DepKes, 2008).

Tabel 3. Hasil uji organoleptis, homogenitas dan $\mathrm{pH}$ gel ekstrak herba pegagan

\begin{tabular}{lcccc}
\hline \multicolumn{1}{c}{ Uji Sifat } & \multicolumn{4}{c}{ Formula } \\
Fisik & F1 & F2 & F3 & F4 \\
\hline Konsistensi & Kental & Kental & Kental & Kental \\
Warna & Putih & Hijau & Hijau & Hijau \\
& Kekuningan & Kehitaman & Kehitaman & kehitaman \\
Bau & Khas Basis & Khas & Khas & Khas \\
Homogenitas & Homogen & Homogen & Pegagan & Pegagan \\
pH & 5 & 5 & 5 & Homogen \\
\hline Keteranon
\end{tabular}

Keterangan :

F1: Kontrol basis (HPMC 8\%)

F2: Gel HPMC 8\% + ekstrak

F3: Gel HPMC 9\% + ekstrak

F4: Gel HPMC 10\% + ekstrak
Pada uji organoleptis gel diamati secara visualdenganmengamatikonsistensi, warna, dan bau sediaan. Gel tanpa penambahan ekstrak (kontrol basis) berwarna putih kekuningan dengan bau khas basis HPMC sedangkan dengan penambahan ekstrak gel berwarna hijau pekat serta menunjukkan adanya bau khas pegagan dengan warna gel yang tidak berubah dengan adanya perbedaan konsentrasi HPMC, konsistensi kental dan sulit dituang. Viskositas ekstrak yang tinggi $4000 \mathrm{dPa}$-s dikarenakan bentuk ekstrak yang liat dan sedikit kandungan air di dalam ekstrak menyebabkan ekstrak menjadi kental.

Salah satu syarat sediaan gel adalah homogen. Syarat homogenitas tidak boleh mengandung bahan kasar yang bisa diraba (Syamsuni, 2006). Homogenitas sedian gel dapat dilihat secara visual dengan hasil pengujian semua formula dihasilkan warna merata serta tidak ditemukan adanya partikel di dalam gel. Hasil uji homogenitas menunjukkan tidak adanya pengaruh variasi konsentrasi HPMC terhadap homogenitas gel.

Pengukuran $\mathrm{pH}$ sangat penting dalam pembuatan sediaan topikal karena $\mathrm{pH}$ yang terlalu asam atau basa akan mudah mengiritasi kulit dan menyebabkan kulit menjadi kering. Pada sediaan gel ektrak herba pegagan dengan adanya variasi konsentrasi gelling agent tidak mempengaruhi perubahan $\mathrm{pH}$. Semua formula memiliki $\mathrm{pH}$ yang sama yaitu 5 , yang berarti masih dalam range $\mathrm{pH}$ normal kulit sehingga bila digunakan akan meningkatkan kenyamanan pada kulit dengan luka bakar. Ini dikarenakan sifat dari HPMC yang netral, tahan terhadap pengaruh asam dan basa sehingga dapat menjaga kestabilitas pH gel (Roger, 2009).

\section{Hasil Uji Viskositas}

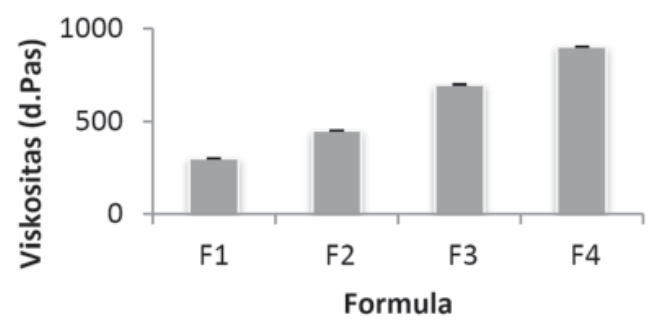

Gambar 3. Diagram Viskositas Gel 
Keterangan :

F1: Kontrol basis (HPMC $8 \%$

F2: Gel HPMC $8 \%$ + ekstrak

F3: Gel HPMC 9\% + ekstrak

F4: Gel HPMC 10\% + ekstrak

Peningkatan viskositas sediaan gel ekstrak herba pegagan dipengaruhi oleh kenaikan konsentrasi gelling agent HPMC (Gambar 3). Pada formula dengan penambahan ekstrak viskositas menjadi meningkat dibanding dengan formula kontrol basis (tanpa ekstrak). Ini dikarenakan viskositas dari ekstrak (4000 d-Pas) yang sifatnya mengentalkan, semakin besar konsentrasi HPMC yang digunakan maka sediaan akan semakin kental. Viskositas menyatakan tahanan dari suatu cairan untuk mengalir, semakin tinggi viskositas maka semakin besar pula tahanannya (Martin et al., 2008). Hal ini disebabkan viskositas sediaan gel tergantung pada struktur dan berat molekul bahan pembentuk gel atau basis gelyang digunakan. HPMC merupakan polimer turunan selulosa (Gibson, 2001). Menurut Erawati et al, 2005 pada dispersi polimer turunan selulosa, molekul polimer masuk ke dalam rongga yang dibentuk oleh molekul air menyebabkan terjadinya ikatan hidrogen antara gugus hidroksil $(-\mathrm{OH})$ dari polimer dengan molekul air. Ikatan hidrogen ini yang berperan dalam hidrasi pada proses swelling dari suatu polimer, sehingga peningkatan konsentrasi HPMC menyebabkan gugus hidroksil yang berikatan semakin banyak sehingga viskositas sediaan semakin meningkat.

3. Hasil Uji Waktu Melekat

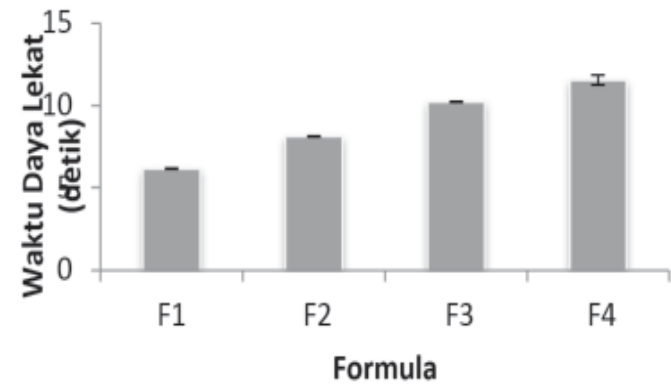

Gambar 4. Diagram Hasil Daya Melekat Gel
Keterangan :

F1: Kontrol basis (HPMC 8\%)

F2: Gel HPMC $8 \%+$ ekstrak

F3: Gel HPMC 9\% + ekstrak

F4: Gel HPMC 10\% + ekstrak

Penambahan ekstrak pada formula dapat meningkatkan waktu lekat gel dibandingkan dengan formula kontrol basis (tanpa ekstrak). Ini disebabkan viskositas dari ekstrak herba pegagan yang kental (4000 d-Pas) akan berpengaruh pada viskositas gel yang semakin kental pula, sehingga waktu lekat yang dibutuhkan semakin lama. Hasil daya melekat pada setiap formula menunjukkan adanya peningkatan waktu melekat gel dengan adanya penambahan konsentrasi HPMC (Gambar 4). Hal ini disebabkan HPMC dapat mengembang dan membentuk koloid dengan penambahan air panas (Roger, 2009). Koloid terbentuk karena zat terdispersinya mengabsorbsi medium pendispersinya sehingga menjadi kental dan bersifat lengket, maka dapat disimpulkan dengan meningkatnya konsentrasi HPMC koloid yang terbentuk semakin banyak sehingga akan meningkatkan kekentalan gel yang mengakibatkan meningkatnya daya lekat gel.

\section{Hasil Luas Penyebaran}

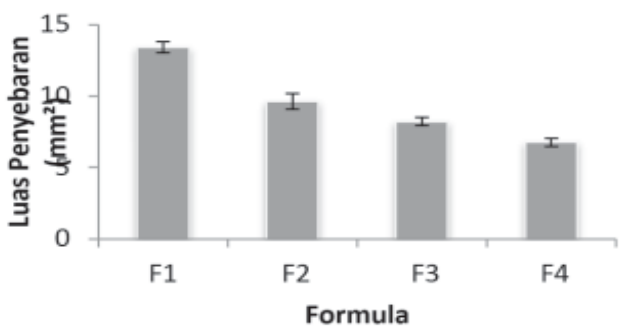

Gambar 5. Diagram Luas Penyebaran Gel

Keterangan :

F1: Kontrol basis (HPMC 8\%)

F2: Gel HPMC 8\% + ekstrak

F3: Gel HPMC 9\% + ekstrak

F4: Gel HPMC 10\% + ekstrak

Hasil luas penyebaran gel dengan pemberian beban yang sama pada masing-masing formula menunjukkan semakin tinggi konsentrasi HPMC maka 
luas penyebarannya semakin menurun (Gambar 5). Hal ini disebabkan seiring dengan peningkatan basis kadar air yang terkandung dalam formula menjadi sedikit yang menyebabkan daya menyebar menjadi turun. Daya sebar bukan merupakan data absolut karena tidak ada literatur yang menyatakan angka pastinya. Jadi data hasil daya menyebar merupakan data yang relatif (Suardi et al., 2008)

\section{Uji Stabilitas Gel}

Salah satu ciri-ciri sedian semipadat yang baik adalah stabil, baik selama penyimpanan dan pemakaiannya karena dipengaruhi oleh kelembaban dan suhu. Hasil pemeriksaan stabilitas secara organoleptis selama penyimpanan 42 hari menunjukkan bahwa tidak terjadinya perubahan homogenitas, warna, bau, viskositas, dan $\mathrm{pH}$, ini menunjukkan bahwa interaksi antara bahan aktif dan bahan pembawa dalam pembentukan sediaan gel tidak mengakibatkan perubahan apapun. Hal ini menunjukkan bahan-bahan dalam formula gel tidak mengalami penguraian selama penyimpanan, ini dikarenakan sifat HPMC yang netral, tahan terhadap asam dan basa, punya $\mathrm{pH}$ stabil antara 3-11, tahan terhadap serangan mikroba dan tahan panas (Suardi et al., 2008). Selain itu adanya metilparaben dan propilparaben sebagai pengawet sangat diperlukan karena gel mempunyai kadar air yang tinggi. Kadar air yang tinggi ini merupakan medium yang baik bagi pertumbuhan jasad renik, sehingga adanya pengawet juga membantu dalam menjaga kestabilan sediaan gel. Sediaan gel yang baik mempunyai kestabilan dalam jangka waktu yang lama dan tidak dipengaruhi oleh lingkungan luar.

Tabel 4. Hasil uji stabilitas gel ekstrak herba Pegagan berbagai konsentrasi

\begin{tabular}{|c|c|c|c|c|c|c|c|c|}
\hline \multirow{2}{*}{ Karakteristik } & \multirow{2}{*}{ Formula } & \multicolumn{7}{|c|}{ Penyimpanan hari ke- } \\
\hline & & 0 & 7 & 14 & 21 & 28 & 35 & 42 \\
\hline \multirow{4}{*}{$\mathrm{pH}$} & F1 & 5 & - & - & - & - & - & - \\
\hline & $\mathrm{F} 2$ & 5 & - & - & - & - & - & - \\
\hline & F3 & 5 & - & - & - & - & - & - \\
\hline & F4 & 5 & - & - & - & - & - & - \\
\hline \multirow{4}{*}{$\begin{array}{c}\text { Viskositas } \\
(\mathrm{dPa}-\mathrm{s})\end{array}$} & $\mathrm{F} 1$ & 300 & - & - & - & - & - & - \\
\hline & $\mathrm{F} 2$ & 450 & - & - & - & - & - & - \\
\hline & F3 & 700 & - & - & - & - & - & - \\
\hline & F4 & 900 & - & - & - & - & - & - \\
\hline \multirow{4}{*}{ Bau } & $\mathrm{F} 1$ & Khas basis & - & - & - & - & - & - \\
\hline & $\mathrm{F} 2$ & Bau pegagan & - & - & - & - & - & - \\
\hline & F3 & Bau pegagan & - & - & - & - & - & - \\
\hline & $\mathrm{F} 4$ & Bau pegagan & - & - & - & - & - & - \\
\hline \multirow{4}{*}{ Warna } & $\mathrm{F} 1$ & Putih kekuningan & - & - & - & - & - & - \\
\hline & $\mathrm{F} 2$ & Hijau kehitaman & - & - & - & - & - & - \\
\hline & F3 & Hijau kehitaman & - & - & - & - & - & - \\
\hline & $\mathrm{F} 4$ & Hijau kehitaman & - & - & - & - & - & - \\
\hline \multirow{4}{*}{ Konsistensi } & $\mathrm{F} 1$ & Kental & - & - & - & - & - & - \\
\hline & $\mathrm{F} 2$ & Kental & - & - & - & - & - & - \\
\hline & F3 & Kental & - & - & - & - & - & - \\
\hline & $\mathrm{F} 4$ & Kental & - & - & - & - & - & - \\
\hline
\end{tabular}

Keterangan :

F1: Kontrol basis (HPMC 8\%)

F2: Gel ektrak + HPMC 8\%

F3: Gel ektrak + HPMC 9\%

F4: Gel ektrak + HPMC 10\%

-: menunjukkan tidak adanya perubahan 


\section{Hasil Pengujian Efek Penyembuhan Luka Bakar}

Pada penelitian ini kontrol positif yang digunakan adalah Bioplacenton ${ }^{\circledR}$. Kontrol negatif dimaksudkan untuk mengetahui kecepatan penyembuhan luka bakar tanpa dilakukan pemberian obat (tidak diberi perlakuan). Kandungan dalam pegagan yang berperan penting dalam proses penyembuhan luka bakar adalah asiaticoside (Sikarrepaisan et al., 2008) yang merupakan saponin yang memacu pembentukan kolagen, yaitu protein struktur yang berperan dalam proses penyembuhan luka (MacKay \& Miller, 2003), mampu menurunkan fibrosis pada luka sehingga mencegah pembentukan bekas luka baru.
Hasil uji penyembuhan luka bakar pada keenam sediaan menunjukkan adanya perbedaan waktu dalam penyembuhan luka, sedangkan pada ketiga sediaan dengan variasi konsentrasi HPMC menunjukkan bahwa semakin tinggi konsentrasi HPMC maka semakin lama waktu yang dibutuhkan untuk kesembuhan luka bakarnya. Hal ini disebabkan semakin tinggi konsentrasi HPMC maka semakin tinggi pula viskositasnya, sehingga semakin lama kecepatan absorbsi obat yang masuk ke dalam kulit. Rata-rata waktu penyembuhan luka bakar yang paling cepat: kontrol positif $>$ formula $2>$ formula $3>$ formula 4 $>$ formula $1>$ kontrol negatif.

Tabel 5. Waktu penyembuhan luka bakar setelah pemberian ekstrak pegagan dengan gelling agent HPMC

\begin{tabular}{|c|c|c|c|c|c|c|}
\hline \multirow{2}{*}{ Perlakuan } & \multicolumn{5}{|c|}{ Lama penyembuhan (hari) kelinci ke : } & \multirow{2}{*}{ Mean $\pm \mathrm{SD}$} \\
\hline & 1 & 2 & 3 & 4 & 5 & \\
\hline Kontrol positif (bioplacenton) & 15 & 14 & 16 & 13 & 13 & $14,20 \pm 1,30^{*}$ \\
\hline Kontrol negatif (tanpa perlakuan) & 23 & 24 & 24 & 24 & 22 & $23,40 \pm 0,89$ \\
\hline Kontrol basis HPMC & 23 & 20 & 23 & 21 & 22 & $21,80 \pm 1,30$ \\
\hline Pegagan+HPMC 8\% & 17 & 16 & 19 & 18 & 18 & $17,60 \pm 1,14^{*}$ \\
\hline Pegagan+HPMC 9\% & 19 & 21 & 19 & 18 & 20 & $19,40 \pm 1,14^{*}$ \\
\hline Pegagan + HPMC $10 \%$ & 20 & 20 & 21 & 19 & 22 & $20,40 \pm 1,14^{*}$ \\
\hline
\end{tabular}

Keterangan : * : berbeda bermakna dengan kontrol negatif $(\mathrm{p}<0,05)$

Tabel 6. Pengujian dan deteksi hasil uji skrining fitokimia ekstrak etanol herba pegagan

\begin{tabular}{|c|c|c|c|}
\hline Senyawa & Cara pengujian & Deteksi hasil & Hasil \\
\hline Flavonoid & $\begin{array}{l}\text { Ekstrak yang sudah dipekatkan diletakkan di cawan porselen, } \\
\text { ditambahkan asam oksalat dan asam borat secukupnya lalu diuapkan } \\
\text { sampai kering. Setelah itu ditambah } 2 \mathrm{ml} \text { dietileter }\end{array}$ & $\begin{array}{l}\text { Positif apabila terjadi } \\
\text { fluoresensi kuning di UV } 366\end{array}$ & + \\
\hline Saponin & $\begin{array}{l}\text { Ekstrak dimasukkan dalam tabung reaksi, kemudian ditambah dengan air } \\
\text { lalu dikocok kuat }\end{array}$ & Positif jika terbentuk buih & + \\
\hline Alkaloid & $\begin{array}{l}\text { Ekstrak dimasukkan dalam tabung reaksi, kemudian ditambah } 5 \text { tetes } \mathrm{CCl}_{4} \\
\text { dan pereaksi Meyer }\end{array}$ & $\begin{array}{l}\text { Positif jika terbentuk endapan } \\
\text { putih }\end{array}$ & - \\
\hline Tanin & Ekstrak dimasukkan dalam tabung reaksi, kemudian ditetesi larutan $\mathrm{FeCl}_{3}$ & $\begin{array}{l}\text { Positif jika warna larutan } \\
\text { berubah menjadi biru tua }\end{array}$ & + \\
\hline Terpenoid & Ekstrak ditambah $1 \mathrm{ml}$ asam asetat glasial dan $1 \mathrm{ml} \mathrm{H}_{2} \mathrm{SO}_{4}$ & $\begin{array}{l}\text { Positif jika warna larutan } \\
\text { berubah menjadi merah }\end{array}$ & + \\
\hline
\end{tabular}

Pada tabel 5 kontrol negatif memberi kesembuhan hampir setara dengan kontrol basis, ini dikarenakan jaringan sel yang rusak dapat beregenerasi dengan sendirinya, sehingga penyembuhan secara spontan tanpa pemberian obat dapat terjadi. Kontrol negatif dengan formula penambahan ekstrak memperlihatkan perbedaan lama penyembuhan luka bakarnya. Ini disebabkan adanya zat aktif asiaticoside yang terkandung di ekstrak yang memicu proses penyembuhan luka semakin cepat.

Kecepatan penyembuhan luka bakar dapat dipengaruhi oleh kedalaman luka yang telah dibuat. Semakin dalam luka bakar yang dibuat maka membutuhkan waktu lama untuk sembuh. Pada penelitian ini gel ekstrak herba pegagan dengan basis HPMC $8 \%$ merupakan formula yang paling efektif dalam memberikan efek 
dibanding dengan sediaan gel ekstrak herba pegagan basis HPMC 9\% dan 10\%. Dapat disimpulkan bahwa dengan peningkatan konsentrasi HPMC viskositasnya semakin besar yang akan mempengaruhi lama penyembuhan luka bakar, menurunkan luas penyebaran, meningkatkan waktu melekat, tanpa mempengaruhi perubahan $\mathrm{pH}$ pada sediaan gel ekstrak herba pegagan.

Berdasarkan uji tabung dalam ekstrak etanol herba pegagan mengandung flavonoid, terpenoid, saponin dan tanin. Menurut Sikarrepaisan et al, (2008), kandungan asiacoside yang merupakan suatu saponin dapat memacu pembentukan kolagen yang akan mempercepat penyembuhan luka.

\section{SIMPULAN}

Berdasarkan hasil penelitian dapat disimpulkan bahwa :

1. Variasi konsentrasi gelling agent HPMC mempengaruhi sifat fisik gel ekstrak herba pegagan (Centella asiatica L. Urban) yaitu kenaikan konsentrasi gelling agent HPMC menyebabkan peningkatan viskositas, daya lekat dan menurunkan daya sebar.

2. Semakin rendah konsentrasi gelling agent HPMC maka semakin cepat penyembuhan luka bakar pada kulit punggung kelinci jantan New Zealand, yaitu konsentrasi $8 \% \quad(16,4 \pm 0,55)$ hari, konsentrasi $9 \% \quad(18 \pm 0,71)$ hari dan konsentrasi $10 \%(19,8 \pm 0,84)$ hari.

\section{SARAN}

Perlu dilakukan penelitian lanjutan dalam pembuatan gel ekstrak herba pegagan dengan gelling agent HPMC yang dioptimasi terlebih dahulu.

\section{UCAPAN TERIMA KASIH}

Terima kasih kami ucapkan kepada Fakultas Farmasi Universitas Muhammadiyah Surakarta yang telah mendanai penelitian ini melalui Penelitian Kolaboratif antara Dosen dan Mahasiswa

\section{DAFTAR PUSTAKA}

DepKes RI, 2008, Farmakope Herbal Indonesia, 113-115, Departemen Kesehatan Republik Indonesia, Jakarta.

Erwati, Tristiana, Rosita, N. , Hendroprasetyo, W. \& Dien R. J., 2005, Pengaruh Jenis Basis
Gel Dan Penambahan $\mathrm{NaCl}(0.5 \%$-b/b) Terhadap Intensitas Echo Gelombang Ultrasonik Sediaan Gel Untuk Pemeriksaan USG (Acoustic Coupling Agent), Airlangga Journal of Pharmacy, 5 (2).

Gibson, M., 2001, Pharmaceutical Preformulation and Formulation, 546-550, CRC Press, United States of America.

Grace, A. P. \& Borley, N. R., 2007, Ilmu Bedah Edisi III, 87, Penerbit Erlangga, Jakarta.

Kibbe, A.H., 2004, Handbook of Pharmaceutical Exipients, Third Edition, 18-19, 462-469, 629-631, Pharmaceutical Press. London.

Kim, W.J., Kim, J., Veriansyah, B., Kim, J.D., Lee, S.G., \& Winata, R.R.T., 2009, Extraction of Bioactive Components from Centella asiatica Using Subcritical Water, The Journal of Supercritical Fluid, 48, 211-216

Lee, T.K., \& Vairappan, C.S., 2011, Antioxidant, Antibacterial and Cytotoxic Activities of Essential Oils and Ethanol Extracts of Selected South East Asian Herbs, J Med Plant Res, 5 (21), 5284-5290

MacKay D. \& Miller A. L., 2003, Nutritional Support for Wound Healing, Alternative Medicine Review, 8, 369-370.

Madan, J. \& Singh, R., 2010, Formulation and Evaluation of Aloe vera Gels, Int J Ph Sci, 2 (2) : 551-555

Martin, A., Swarbrick, J. \& Cammarata, A., 2008, Farmasi Fisik, Edisi Ketiga, Penerbit UI Press, Jakarta.

Rismana, E., 2010, Pengembangan Formulasi Sediaan Wound Healing Menggunakan Bahan Aktif Kitosan dan Ekstrak Pegagan, BPPT, Jakarta

Rogers, T.L., 2009, Hypromellose, Rowe, R. C., Paul J. S., \& Marian E. Q., Sixth Edition, 326-329, Handbook of Pharmaceutical Excipient, Pharmaceutical Press, USA.

Sikarrepaisan, P., Suksamrarn, A., \& Supaphol, P., 2008, Electrospun Gelatin Fiber Mats Containing A Herbal Centella asiatica Extract and Release Characteristic of Asiaticoside, Nanotechnology, 2.

Suardi, M., Armenia \& Maryawati, A., 2008, Formulasi dan Uji Klinik Gel Anti Jerawat Benzoil Peroksida-HPMC, Karya Ilmiah, Fakultas Farmasi Universitas Andalas, Sumatra Barat.

Sudarsono, Gunawan, D., Wahyuono, S., Donatus, I.A., \& Purnomo, 2002, Tumbuhan Obat II, 42-45, Pusat Studi Obat Tradisional UGM, Yogyakarta 
Suratman, Sumiwi, S.A., \& Gozali, D., 1996, Pengaruh Ekstrak Antanan dalam Bentuk Salep, Krim dan Jelly terhadap Penyembuhan Luka Bakar, Cermin Dunia Kedokteran, 108 : 3136

Syamsuni, H., 2006, Farmasetika Dasar dan Hitungan Farmasi, 104, EGC, Jakarta
Teti \& Fina, 2011, Formulasi Gel Pengupas Kulit Mati yang Mengandung Sari Buah Nanas (Ananas comosus L.) antara 17 sampai 78\%, Jurnal Ilmu Kefarmasian Indonesia, 104-109.

Wasito, H., 2011, Obat Tradisional Kekayaan Alam, 78-80, Graha Ilmu, Yogyakarta. 